\title{
Survey of Teacher's Views on Teaching Evaluation Method: An Implication for Education
}

\author{
Desalegn Alemu ${ }^{1 *}$, M.V.R. Raju ${ }^{2}$
}

\section{ABSTRACT}

The purpose of the present study was to survey teachers views on the performance evaluation methods employed in the wolkite, Wachemo and Welaita sodo University. 280 randomly selected participants from the three universities were involved in the survey. Data gathered through questionnaire survey were analyzed using descriptive analysis method. The questionnaire surveys were used to examine the teachers views on the existing evaluation method. The present finding revealed that the performance evaluation method lacks objectivity, do not support teacher's professional development and the evaluation procedures are in accordance with the purpose of evaluation. Based on the findings and discussions of study, conclusion and recommendations were forwarded.

Keywords: Performance evaluation method, objectivity, evaluation procedure, professional practice

What makes university distinctive is the quality of academic and non academic staffs working in the organization and its production of competent students. Educational psychologists have already designed a number of ways to assess institutional quality. Of the ways having competent staff plays a pivotal role in success of the competences and standards desired from institutions.

The question comes on how to assess the teachers instructional effectiveness. In answering this question universities in Ethiopia are implementing the student evaluation of teaching in which students rate their teachers actual performance in a classroom.

Research findings are supporting the importance of using student evaluation of teaching in the way to gain feedback for the achievement of desired objectives (Way 1993); Cashin (2003). However important student evaluation of teaching, researchers are questioning the validity and

\footnotetext{
${ }^{1}$ Research Scholar, Department of Psychology and parapsychology, Andhra University, India

${ }^{2}$ Professor, Department of Psychology and parapsychology, Andhra University, India

*Responding Author
}

Received: January 25, 2017; Revision Received: February 10, 2017; Accepted: February 15, 2017

(C) 2017 Alemu D, Raju MVR; licensee IJIP. This is an Open Access Research distributed under the terms of the Creative Commons Attribution License (www.creativecommons.org/licenses/by/2.0), which permits unrestricted use, distribution, and reproduction in any Medium, provided the original work is properly cited. 


\section{Survey of Teacher's Views on Teaching Evaluation Method: An Implication for Education}

reliability of the instrument (Berk, 2008). The issue of validity of the student rating is also questioned by scholars such as (Koon and Murray, 1995, Feldman1993).

The instrument is a survey distributed to students to evaluate their teachers instructional effectiveness. In support of the above idea (Centra, 1997) asserted that if student evaluation is managed appropriately it will have a significant contribution for improving the instructional quality.

Findings by Berk (2008), Way (1993) revealed that the student evaluation lacks objectivity and it is highly subjected to leniency. Several findings are revealing that teachers actual classroom teaching is not related to their students rating (McKeachie, 190). Putting differently, teachers performing poor in a classroom may get higher ratings and vice versa.

Research findings confirmed that students tend to evaluate their teachers with a conception of gaining grade or based on his personal characteristics in the classroom (Marsh \&Roche, 1993).

Because student rating is not representing the actual teachers performance it is not uncommon to find the hostility between teachers and students in the respective programs (Spencer, 1992). Evidences by researchers also demonstrated that the items that students rate also not related to their experience and background. The questions require professional experiences than evaluating the actual classroom performance (Seldin, 1993).

The rationales behind conducting the present study are the following: First, research findings are seriously questioning the validity and reliability of the performance evaluation method in which students rate. Second, most teacher are complaining about the existing performance evaluation method. Lastly. The researcher's practical experience revealed that teachers actual classroom practice and their evaluation result are not related.

\section{Objectives of the study}

The major purpose of this study was to examine views of teachers on the performance evaluation method employed at Wolkite University, Wachemo University and Welaita Sodo University. Specifically, the purposes of this study were to:

1. examine the views of teachers on the performance evaluation method

2. investigate the problems related to the teacher performance evaluation method

3. outline implication to the current teacher's teaching performance evaluation method to education

\section{RESEARCH METHODOLOGY}

The present study aimed at examining the views of teachers on the performance evaluation method employed at Wolkite University, Wachemo and Welaita Sodo University. Hence, in this study descriptive research design was employed. 
The target population of this study was instructors from Wolkite University, Wachemo and Welaita Sodo University. From the Total of 750 teachers in Welaita sodo University 130 teachers were selected, From Wachemo University 80 Teachers were selected from 430 teachers and 90 teachers were selected from Wolkite University from the total of 500 teachers. Hence, a total of 300 participants were selected randomly. However, 20 teachers failed to return the questionnaire in which 10 teachers from Wachemo university,6 teachers from Welaita Sodo University and 4 Teachers From Wolkite University. Therefore, The questionnaire analysis was done based on the data obtained from 280 teachers. To select the samples simple random sampling were employed using the lottery method. The survey containing 18 items is adapted from Iowa Standards-Based Evaluation teacher Survey Instrument.

\section{RESULT}

Data gathered through survey questionnaire were analyzed as follows the analysis was done in accordance with the leading questions and items in the survey questionnaire.

Table 1 Descriptive Statistics showing views of teachers on the objectivity of performance evaluation methods

\begin{tabular}{|l|l|l|l|l|l|}
\hline & \multicolumn{1}{|c|}{ N } & Minimum & Maximum & Mean & $\begin{array}{c}\text { Std. } \\
\text { Deviation }\end{array}$ \\
\hline $\begin{array}{l}\text { The teacher performance evaluation is } \\
\text { realistic }\end{array}$ & 280 & 1 & 5 & 2.06 & .924 \\
\hline $\begin{array}{l}\text { The teacher performance evaluation } \\
\text { procedure is fair }\end{array}$ & 280 & 1 & 5 & 2.29 & .939 \\
\hline $\begin{array}{l}\text { The evaluation result represent my } \\
\text { professional practice }\end{array}$ & 280 & 1 & 5 & 2.29 & .900 \\
\hline $\begin{array}{l}\text { The evaluation result shows the } \\
\text { effective teachers qualities }\end{array}$ & 280 & 1 & 5 & 2.24 & .955 \\
\hline $\begin{array}{l}\text { I am satisfied with the current } \\
\text { evaluation system }\end{array}$ & 280 & 1 & 5 & 1.79 & 1.016 \\
\hline $\begin{array}{l}\text { The evaluation result shows my actual } \\
\text { performance of teaching }\end{array}$ & 280 & 1 & 5 & 2.14 & .925 \\
\hline The evaluation system is objective & 280 & 1 & 5 & 2.03 & .909 \\
\hline $\begin{array}{l}\text { Objectivity of Performance Evaluation } \\
\text { Method }\end{array}$ & 280 & 7 & 35 & 14.84 & 6.002 \\
\hline Valid N (listwise) & 280 & & & & \\
\hline
\end{tabular}

As it is clearly observed in the Table 1, the mean of teachers views on objectivity of the performance evaluation method with standard deviation were $(\mathrm{M}=2.06, \mathrm{SD}=.924 ; \mathrm{M}=2.29, \mathrm{SD}=$ $.939 ; \mathrm{M}=2.29, \mathrm{SD}=.900 ; \mathrm{M}=2.24, \mathrm{SD}=.955 ; \mathrm{M}=1.79, \mathrm{SD}=1.016 ; \mathrm{M}=2.14, \mathrm{SD}=.925 ; \mathrm{M}=2.03, \mathrm{SD}=.909$ )respectively.From the result it is possible to infer that the performance evaluation method lacks objectivity. Hence, there is a need to amend the evaluation method so as to meet the objectivity. 
Survey of Teacher's Views on Teaching Evaluation Method: An Implication for Education

Table 2 Descriptive Statistics showing views of teachers on the role of performance evaluation for professional Practice

\begin{tabular}{|l|l|l|l|l|l|}
\hline & N & Minimum & Maximum & Mean & $\begin{array}{c}\text { Std. } \\
\text { Deviation }\end{array}$ \\
\hline $\begin{array}{l}\text { The teaching evaluation system is related to } \\
\text { my responsibilities }\end{array}$ & 280 & 1 & 5 & 2.09 & 1.188 \\
\hline $\begin{array}{l}\text { The teacher performance evaluation method } \\
\text { meets my expectations }\end{array}$ & 280 & 1 & 5 & 2.20 & 1.070 \\
\hline $\begin{array}{l}\text { I have changed my method of teaching } \\
\text { because of the evaluation method }\end{array}$ & 280 & 1 & 5 & 1.80 & 1.043 \\
\hline $\begin{array}{l}\text { The teacher evaluation method have positively } \\
\text { challenged me to improve my teaching } \\
\text { practice }\end{array}$ & 280 & 1 & 5 & 2.11 & .886 \\
\hline $\begin{array}{l}\text { My students' academic achievement has been } \\
\text { improved as a result of the evaluation method }\end{array}$ & 280 & 1 & 5 & 2.36 & .860 \\
\hline $\begin{array}{l}\text { The evaluation result helped me to learn how } \\
\text { I can improve my Instruction }\end{array}$ & 280 & 1 & 5 & 2.23 & .882 \\
\hline $\begin{array}{l}\text { The evaluation result helped me for my } \\
\text { professional development }\end{array}$ & 280 & 1 & 5 & 2.30 & .873 \\
\hline Evaluation For Professional Practice & 280 & 11 & 31 & 15.07 & 4.524 \\
\hline Valid N (listwise) & 280 & & & & \\
\hline
\end{tabular}

As it is clearly shown in the Table 2, the mean of teachers views on contribution of the performance evaluation method for their professional development with standard deviation were $(\mathrm{M}=2.09, \mathrm{SD}=1.188 ; \mathrm{M}=2.20, \mathrm{SD}=1.070 ; \mathrm{M}=1.80, \mathrm{SD}=.1 .043 ; \mathrm{M}=2.11, \mathrm{SD}=.886 ; \mathrm{M}=2.36, \mathrm{SD}=.860$; $\mathrm{M}=2.23, \mathrm{SD}=.882 ; \mathrm{M}=2.30, \mathrm{SD}=.873$ )respectively.From the result it is possible to conclude that the current performance evaluation method is not supporting teachers to improve their professional practice. Hence, serious consideration needs to be given in designing the performance evaluation method that can assist teachers in improving their professional practice

Table 3Descriptive Statistics showing views of teachers on performance evaluation procedures

\begin{tabular}{|l|l|l|l|l|l|}
\hline & N & Minimum & Maximum & Mean & $\begin{array}{c}\text { Std. } \\
\text { Deviation }\end{array}$ \\
\hline $\begin{array}{l}\text { I have the clear idea of the purpose of } \\
\text { evaluation system }\end{array}$ & 280 & 1 & 5 & 3.59 & .733 \\
\hline The evaluation result is given timely & 280 & 1 & 5 & 2.07 & .931 \\
\hline $\begin{array}{l}\text { Students have clear orientation for the } \\
\text { performance evaluation purpose }\end{array}$ & 280 & 1 & 5 & 2.91 & 1.092 \\
\hline $\begin{array}{l}\text { My head department spend some time for } \\
\text { feedback after the performance evaluation } \\
\text { result }\end{array}$ & 280 & 1 & 5 & 1.80 & 1.178 \\
\hline The Evaluation Procedure & 280 & 4 & 20 & 10.36 & 3.701 \\
\hline Valid N (listwise) & 280 & & & & \\
\hline
\end{tabular}




\section{Survey of Teacher's Views on Teaching Evaluation Method: An Implication for Education}

As it is clearly shown in the Table 2, the mean of teachers views on performance evaluation procedure with standard deviation were $(M=3.59, S D=.733 ; M=2.07, S D=.931, M=2.91$, $\mathrm{SD}=.1 .092 ; \mathrm{M}=1.80, \mathrm{SD}=1.178$; respectively. From the result it is possible to understand that the current performance evaluation method procedure is not well conducted to meet the expected requirements. Therefore, serious consideration needs to be given in following appropriate procedures that can help teachers know their real teaching performance.

\section{DISCUSSION}

The present study survey of teachers views were done on the current performance evaluation method. In this part, the discussions were organized as per the result obtained from the analysis of survey questionnaire. In the discussion relevant literatures were reviewed to support the findings of the present study. Following the discussion, an implication for further research is forwarded.

The present study revealed that teachers are dissatisfied on the current evaluation system. Besides, the evaluation systems do not support them to improve their practice. The result of the present study is in consistent with research findings that assert that dissatisfaction with evaluation approaches that provide little guidance for teachers' efforts to improve practice (Moore Johnson, 1990; Stiggens and Duke, 1988) has also been an influence. This implies that teachers need to have an evaluation system that assesses their potential.

The current study demonstrated that there should be standardized method of teacher evaluation. This finding is supported by the findings of (Danielson, 1996; Danielson and McGreal, 2000). Therefore, if there is a standardized system of evaluation the problems related to subjectivity will be minimized. Moreover, standards-based evaluation can lead to more student academic achievement.

The results in the present study indicated that teachers were not receiving feedback from their head departments. Feedback is very important to improve their professional practice there by improve their students' academic achievement. Supporting this idea, Sanders (2000) observed that once teachers are given feedback pertaining to classroom-level instructional outcomes, they start to modify their instruction to address their weak areas. It is important, however, that when administrators make decisions and provide feedback to teachers on their performance, that the information is a valid measure of their actual job performance, which means it should include a teachers' responsibilities both in-class and out-of-class.

The findings in the present study demonstrated that teachers are not evaluated based on the actual ability of their teaching rather students evaluate based on grade and likes and dislikes of their teacher. Supporting this idea, Schalock, Schalock, Cowart, and Myton (1993) stated that if the purpose of teaching is to nurture learning, then both teachers and departments as a whole 


\section{Survey of Teacher's Views on Teaching Evaluation Method: An Implication for Education}

should be judged for their effectiveness on the basis of what and how much students learn. Thus, Research strongly supports the argument that ineffective teachers negatively impact students' learning while effective teachers lead to higher student achievement growth.

The current study indicated that the teacher evaluation do not helped teachers to improve their students' academic achievement however teacher evaluation should depend on students academic achievement. Research findings asserted that linking student academic progress with teacher evaluation offers significant potential because progress provides an objective measure of teacher effectiveness and recognizes that students bring different levels of achievement to each classroom; can serve as meaningful feedback for instructional improvement; can serve as a barometer of success and a motivation tool; and is derived from student assessment and is an integral facet of instruction (Rivkin, Hanushek, \& Kain, 2005).

The finding of the present study also revealed that students do not have the necessary orientation and knowledge to evaluate the professional aspect of teacher evaluation. Related to this, Wachtel (1998) is among those who additionally question whether students have the capacity to actually evaluate teaching and teaching effectiveness. This shows that students cannot be able to evaluate their teachers according the stated evaluation method.

The results in the present study portrayed that the criteria used for teacher evaluation included in appropriate items that are not related to teachers professional practice. To prepare good instrument there is a need to use meaningful criteria as an important piece for successful teacher evaluation (Machell, 1995; Stiggans \& Duke, 1988).

The results in the present study depicted that the current evaluation system is not supporting teachers for teachers professional development. In line with this idea,(Wilson \& Wood, 1996) identified that the use of more flexible evaluation procedures and instruments as more aptly promoting professional growth for all teachers.

The finding of the current study showed that the current evaluation system is not fair, reliable and valid. In regards to establishing validity and reliability, findings from research indicated that it was important to develop an evaluation system that was reliable, was valid and one that promoted fairness (McLaughlin \& Pfeifer, 1988; Wise et al., 1984). Theorists also supported the idea that evaluation systems should demonstrate validity, reliability and fairness (Dwyer, 1998; Shinkfield \& Stufflebeam, 1995).

The findings of the present study revealed that the administration of teacher performance evaluation is not conducted in objective manner. In regards to establishing a objective evaluation process, experts agreed that monitoring the implementation of an evaluation system should be objective to achieve its effectiveness (Annunziata, 1997;Bradshaw \& Glatthorn, 2001). 


\section{Survey of Teacher's Views on Teaching Evaluation Method: An Implication for Education}

According to the results of the present study, students tend to fill the teacher evaluation form without having clear orientation. In regards to systematic communication of expectations, there was agreement among experts that effective communication about the policies and procedures prior to implementing the teacher evaluation system, and during the evaluation process itself, was essential to successful systems (Darling-Hammond et al., 1983; Stronge, 1997; Stronge \& Tucker, 1999).

The present study result outlined that there is no feedback provided for teacher after performance evaluation is conducted. Research studies found that effective feedback was one ofthe most important attributes of successful teacher evaluation (Lawler, 1992; Machell, 1995; Rindler, 1994). Moreover, when teachers perceived the quality of feedback as being important to the success of an evaluation experience, evaluation was likely to be more effective (Machell, 1995).

The present study have attempted to find out teachers view on the current performance evaluation method but future research is needed on what thought are used by students in evaluating their teachers and what are the better ways of student rating method to employed in the future.

\section{CONCLUSIONS}

Based on the discussion, the following conclusions were drowning:

Excellence is not recognized. A rating scale that does not distinguish the truly outstanding performers from the average ones creates a situation where the exceptional teachers are not identified and cannot be recognized formally.

Professional development is inadequate. Head departments cannot identify the needs of teachers and provide professional development if their shortcomings are never identified.

Beginning teachers do not receive special attention. When evaluation systems do not identify the specific developmental needs of new teachers (who are widely recognized as needing support to build and implement the most effective practices), they do not receive the assistance they need to correct their deficiencies.

Poor performance does not get addressed. Peers that provide teachers with unrealistic ratings rarely dismiss teachers for poor performance, even though they are recognized by other teachers and administrators as being ineffective.

\section{Recommendations}

Based on the forgoing discussions and conclusions the following recommendations were forwarded. Therefore, to improve teacher evaluation system, higher education institutions and policymakers should employ the following strategies: 


\section{Survey of Teacher's Views on Teaching Evaluation Method: An Implication for Education}

1. Higher education institutions have to define academic standards for what every student needs to know. They also must clearly define what a highly qualified teacher needs to know and be able to do before they can purposefully construct a teacher evaluation policy.

2. Institutions should view evaluation as an informational tool to help administrators identify teachers who need additional or specialized assistance and to help individual teachers improve their instructional practices.

3. Institutions should transform evaluation from a traditionally input-based process into an outcome-driven one. They should consider measurable student achievement as a principal outcome on which teachers are evaluated.

4. Career ladders can provide Institutions an opportunity to strengthen teacher evaluation policy and align it with performance-based teaching standards.

\section{Acknowledgments}

The author appreciates all those who participated in the study and helped to facilitate the research process.

Conflict of Interests: The author declared no conflict of interests.

\section{REFERENCES}

Annunziata, J. (1997). Linking teacher evaluation and professional development

Berk, R. A. (2008). Beyond student ratings: A whole new world, a new fantastic point of view. The Professional and Organizational Development Network in Higher Education, 20(1).

Cashin, W. E. (2003). Evaluating college and university teaching: Reflections of a practitioner. In J. C. Smart (Ed.), Handbook of theory and research. Dordrecht: Kluwer Academic Publishers.

Centra, J. (1997). Student ratings of instruction and their relationship to student learning. American Educational Research Journal, 14, 17-24.

Danielson, C., and McGreal, T.L.(2000). Teacher Evaluation to Enhance Professional Practice. Alexandria, VA: Association for Supervision and Curriculum Development.

Darling-Hammond, L. (1990). Teacher evaluation in transition: Emerging roles and evolving methods. In J. Millman, \& L. Darling-Hammond (Eds.), The new handbook of teacher evaluation: Assessing elementary and secondary school teachers. (pp. 17-32). Newbury Park, CA: Sage Publications, Inc.

Dwyer, C. A. (1998). Psychometrics of Praxis III: Classroom Performance Assessments. Journal of Personnel Evaluation in Education 12(2), 163-187.

Feldman, K. (1993). College students' views of male and female college teachers: Part b II-Evidence from students' evaluations of their classroom teachers. Research in Higher Education, 34, 151-211.

Koon, J., \& Murray, H. (1995). Using multiple outcomes to validate student ratings of overall teacher effectiveness. Journal of Higher Education, 66, 61-81.

Lawler, D. W. (1992). An examination of teacher evaluation in Iowa. Unpublished doctoral dissertation, Iowa State University. 


\section{Survey of Teacher's Views on Teaching Evaluation Method: An Implication for Education}

Machell, J. (1995). The teacher evaluation environment: An examination of attributes related to teacher growth. Journal of Personnel Evaluation in Education 9(3), 259-273.

Marsh, H., \& Roche, L. (1993). The use of students' evaluations and an individually structured intervention to enhance teaching effectiveness. American Educational Research Journal, 30, 217-25.

McKeachie, W. (1990). Research on college teaching: The historical background. Journal of Educational Psychology, 82,189-200.

McLaughlin, M. W. (1990). Embracing contraries: Implementing and sustaining teacher evaluation. In J. Millman, \& L. Darling-Hammond (Eds.), The new handbook of teacher evaluation: Assessing elementary and secondary school teachers. (pp. 403-415). Newbury Park, CA: Sage Publications, Inc.

Moore Johnson, S. (1990). Teachers at Work: Achieving Success in Our Schools. NY: Basic Books.

Rivkin, S. G., Hanushek, E. A., \& Kain, J. F. (2005). Teachers, schools, and academic achievement. Econometrica, 73(2), 417-458.

Sanders, W. L. (2000). Value-added assessment from student achievement data: Opportunities and hurdles. Journal of Personnel Evaluation in Education, 14(4), 329-339.

Schalock, H. D., Schalock, M. D., Cowart, B. \& Myton, D. (1993). Extending teacher assessment beyond knowledge and skills: An emerging focus on teacher accomplishments. Journal of Personnel Evaluation in Education, 7, 105-133.

Seldin, P. (1993). The use and abuse of student ratings of professors. Journal of Educational Psychology, 69, 744-747.

Spencer, P. (1992). Improving teacher evaluation. Riverside, C. A.: Riverside Community College.

Stiggens, R.J., and Duke, D. (1988). The Case for Commitment to Teacher Growth: Research on Teacher Evaluation. Albany, NY: State University of New York Press.

Stronge, J. H. (1995). Balancing individual and institutional goals in educational personnel evaluation: A conceptual framework. Journal of Personnel Evaluation in Education 21, 131-151.

Stronge, J. H., \& Tucker, P. D. (2000). Teacher evaluation and student achievement. Washington, DC: National Education Association.

Wachtel, H.K. (1998). Student evaluation of college teaching effectiveness: A brief review. Assessment \& Evaluation in Higher Education, 23(2), 191-211.

Way, D. (1993). Evaluating teaching portfolios: Moving from a competitive to a collaborative culture (2nd ed., Teaching Evaluation Handbook). Ithaca N. Y.: Cornell University Office of Instructional Support.

Wise, A. E., Darling-Hammond, L., McLaughlin, M. W., \& Bernstein, H. T. (1984). Case studies for teacher evaluation: A study of effective practices. Santa Monica, CA: The Rand Corporation.

How to cite this article: Alemu D, Raju MVR (2017), Survey of Teacher's Views on Teaching Evaluation Method: An Implication for Education, International Journal of Indian Psychology, Volume 4, Issue 2, No. 89, ISSN:2348-5396 (e), ISSN:2349-3429 (p), DIP:18.01.087/20170402, ISBN:978-1-365-74162-3 